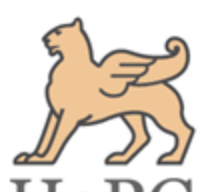

\title{
Strobilanthes mullayanagiriensis and S. bislei (Acanthaceae) - two new species from the Western Ghats, India
}

\author{
Sinjumol Thomas ${ }^{1}$, Bince Mani $^{2^{*}}$, S John Britto ${ }^{3}$ and A K Pradeep ${ }^{4}$ \\ ${ }^{1}$ Department of Botany, Carmel College Mala, Thrissur 680732, Kerala, India \\ ${ }^{2}$ Department of Botany, St. Thomas College Palai, Kottayam 686574, Kerala, India \\ ${ }^{3}$ Rapinat Herbarium and Centre for Molecular Systematics, St. Joseph's College (Autonomous), Tiruchirappalli 620002, Tamil Nadu, India \\ ${ }^{4}$ WWI Innovative Solutions, Kottayam 686576, Kerala, India
}

\section{Article history}

Received: 12 December 2018

Accepted: 10 January 2019

Published: 01 February 2019

\section{Publisher}

Horizon e-Publishing Group

\section{*Correspondence}

Bince Mani

$\triangle$ binsnm@gmail.com

\begin{abstract}
Strobilanthes mullayanagiriensis and S. bislei are plietesial species described for the flora of Western Ghats of India from Karnataka state. Pollen morphology is used as a key character for establishing these two species. Distribution and notes on its allied species are provided along with photographis for facilitating its identification. The former species readily distinguished from its allied species $S$. consanguinea by coriaceous and scabrous leaves with broadly ovate lamina, crenate margin and cuspidate apex, uninterrupted viscous spikes, longer bract: calyx ratio, much shorter corolla and pollen grains with ribs meet at the poles into two groups and one rib completely encircling the pollen. The latter species definitely distinguished from the allied species by uninterrupted viscous inflorescence with sericeous indumentum, calyx exceeds the bract, anthers are held parallel to the filament and ellipsoid pollen grains with slightly twisted ribs.
\end{abstract}

Keywords:

New species; Strobilanthes; Western Ghats

Citation

Thomas S, Mani B, Britto SJ, Pradeep AK. Strobilanthes mullayanagiriensis and S. bislei (Acanthaceae) - two new species from the Western Ghats, India. Plant Science Today 2019;6(1):46-53. https://doi.org/10.14719/pst.2019.6.1.465

Copyright: (c) Thomas et al. (2019). This is an open-access article distributed under the terms of the Creative Commons Attribution License, which permits unrestricted use, distribution, and reproduction in any medium, provided the original author and source are credited (https://creativecommons.org/licenses/by/4.0/).

Indexing: Plant Science Today is covered by Scopus, CAS, AGRIS, CABI, Google Scholar, etc. Full list at http://www.plantsciencetoday.online

\section{Introduction}

The Western Ghats is one of the hotspots in India known for high level of biological diversity and endemism. It is a home to a large number of threatened taxa including several species of Strobilanthes Blume (1). About 150 species of Strobilanthes have been reported from India and among them, 61 species are recorded for the Western Ghats (2-4). During explorations by the authors in Karnataka, interesting specimens of Strobilanthes was collected from Chikkamagaluru and Hassan districts (Fig. 1). The specimens were critically analysed, compared with herbarium specimens in India and abroad and significant study of relevant literature has revealed that the collections do not match any of the recognized species of Strobilanthes $(3,5)$. Therefore, it is described as new to science. 


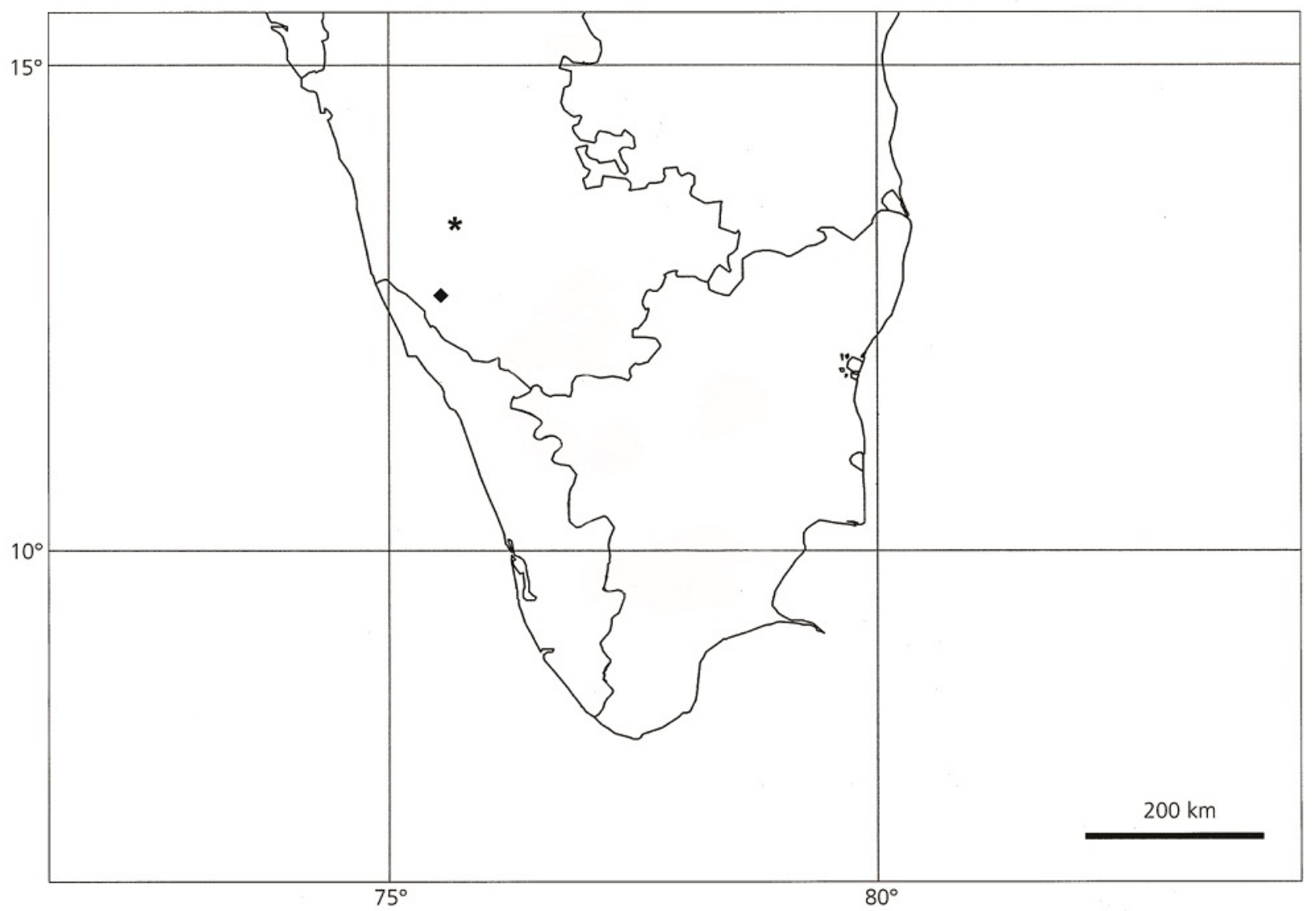

Fig. 1. Distribution of Strobilanthes mullayanagiriensis $(*)$ and S. bislei $(\bullet)$.

Table 1: Comparison of pollen characteristics of new species and the allied taxa.

\begin{tabular}{llllllll}
\hline Species & Pollen class & Shape & Pseudocolpi & P $(\mu \mathrm{m})$ & $\mathrm{E}(\mu \mathrm{m})$ & P:E ratio & Ribs \\
\hline S. mullayanagiriensis & Prolate & Ellipsoid & Wide & $43-47$ & $26-30$ & 1.60 & $14-16$ \\
\hline S. gamblei & Per-prolate & Terete & Wide & $49-53$ & $24-28$ & 1.96 & $16-19$, spiral \\
\hline S. consanguinea & Prolate & Barrel & Narrow & $59-63$ & $37-41$ & 1.60 & $18-21$, spiral \\
\hline S. bislei & Prolate & Ellipsoid & Wide & $46-51$ & $32-34$ & 1.46 & 20-24, slightly twisted \\
\hline
\end{tabular}

\section{Taxonomic treatment}

Strobilanthes mullayanagiriensis S. Thomas, B. Mani, S.J. Britto \& Pradeep A.K., sp. nov. (Fig. 2).

The new species is similar to Strobilanthes consanguinea (Nees) T. Anderson in floral morphology such as spicate inflorescence with ventricose corolla and exserted stamens. However, it differs from $S$. consanguinea in overall vegetative morphology and having pollen grains with ribs united in to two groups at poles and one rib completely encircling the grain. At the same time, the new species shows similarity in vegetative morphology to $S$. canarica Bedd., but differs by overall floral morphology with regard to viscous uninterrupted spikes, bract ovate with long acuminate apex, bract always much longer than calyx, linear calyx lobes terminate with acuminate apex, bi-lipped corolla glabrous on outer surface, corolla lobes unequal and triangular, stamens exserted, pubescence on ovary apex and pollen grains with ribs united in to two groups at poles and one rib completely encircling the grain.

Type: INDIA. Karnataka: Chikkamagaluru District, Manikyadhare waterfalls, $1750 \mathrm{~m}$ MSL., 18 November 2018, Pradeep A.K. \& B. Mani 68840 (holotype RHT!; isotype MH! RHT!).

Erect bushy shrubs, up to $1 \mathrm{~m}$ tall; young shoot angled, canaliculated, mature terete, lenticellate, tomentose. Leaves opposite, symmetrical, broadly ovate, $6.5-9 \times 3.6-5.6 \mathrm{~cm}$, coriaceous, rounded and decurrent at base, cuspidate at apex, crenate-serrate at margin, short hairs present on abaxial surface, adaxial surface scabrous, tomentulose on mid-vein and lateral veins; lateral nerves 7-9 pairs, prominent on both surfaces, raised beneath; petiole $0.5-5 \mathrm{~cm}$ long, brown hairs present on abaxial surface and 


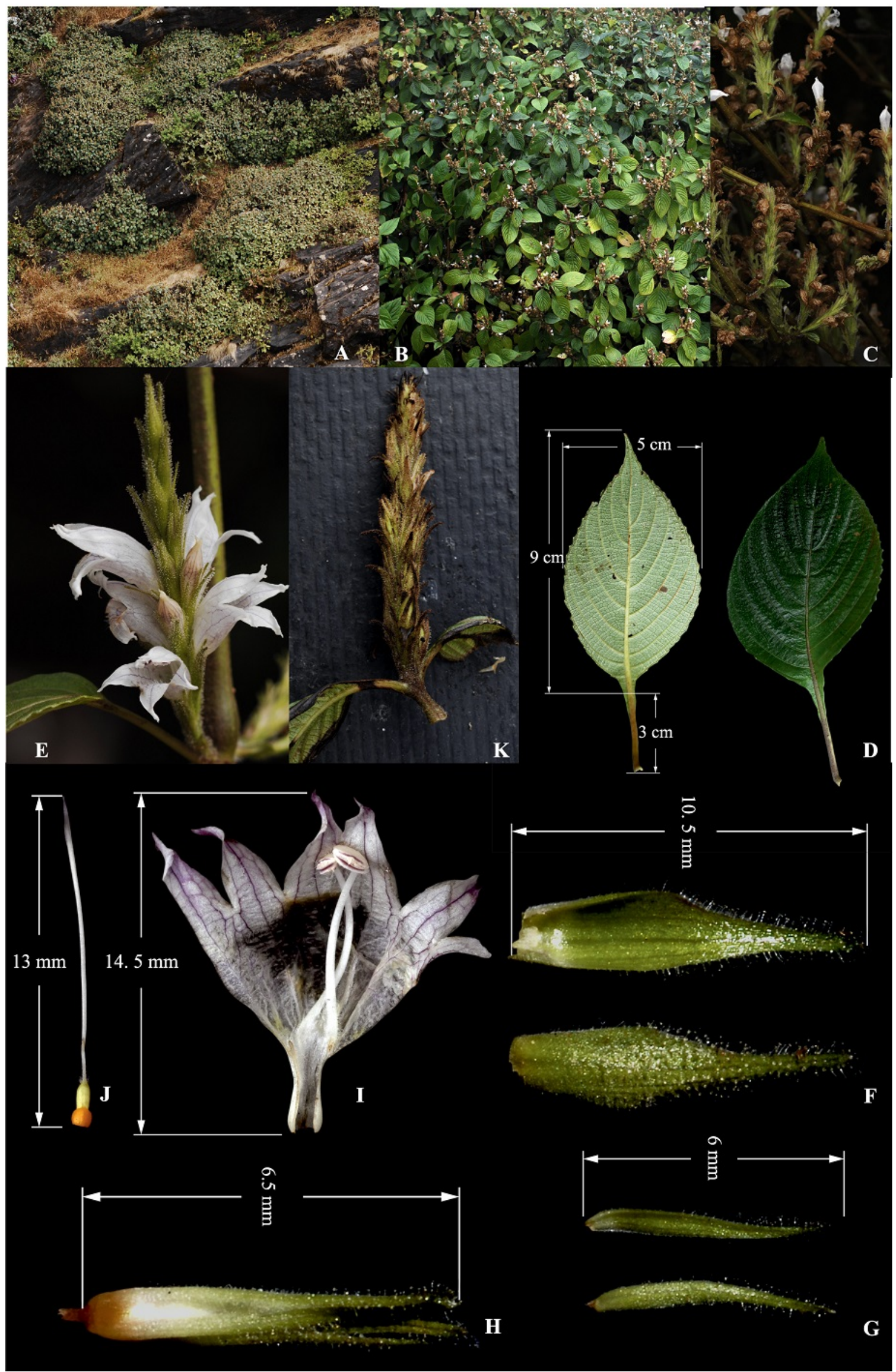

Fig. 2. Strobilanthes mullayanagiriensis sp. nov. A-B. Habit, C. Inflorescence in lower sections, D. Leaves, E. Inflorescence, F. Bracts, G. Bracteoles, H. Calyx, I. Corolla split open showing the epipetalous stamens having anthers held perpendicular to the filament, J. Pistil, K. Young infructescence.

tomentose on adaxial surface; Inflorescences axillary or terminal or lateral uninterrupted spikes, 30-65 × 6-8 mm, 1-3 forked, glandular hairy at anthesis; peduncle tomentose; bracts ovate, 10-10.5 × ca. $2.5 \mathrm{~mm}$, acuminate at apex, abaxial surface tawny tomentose with glandular 


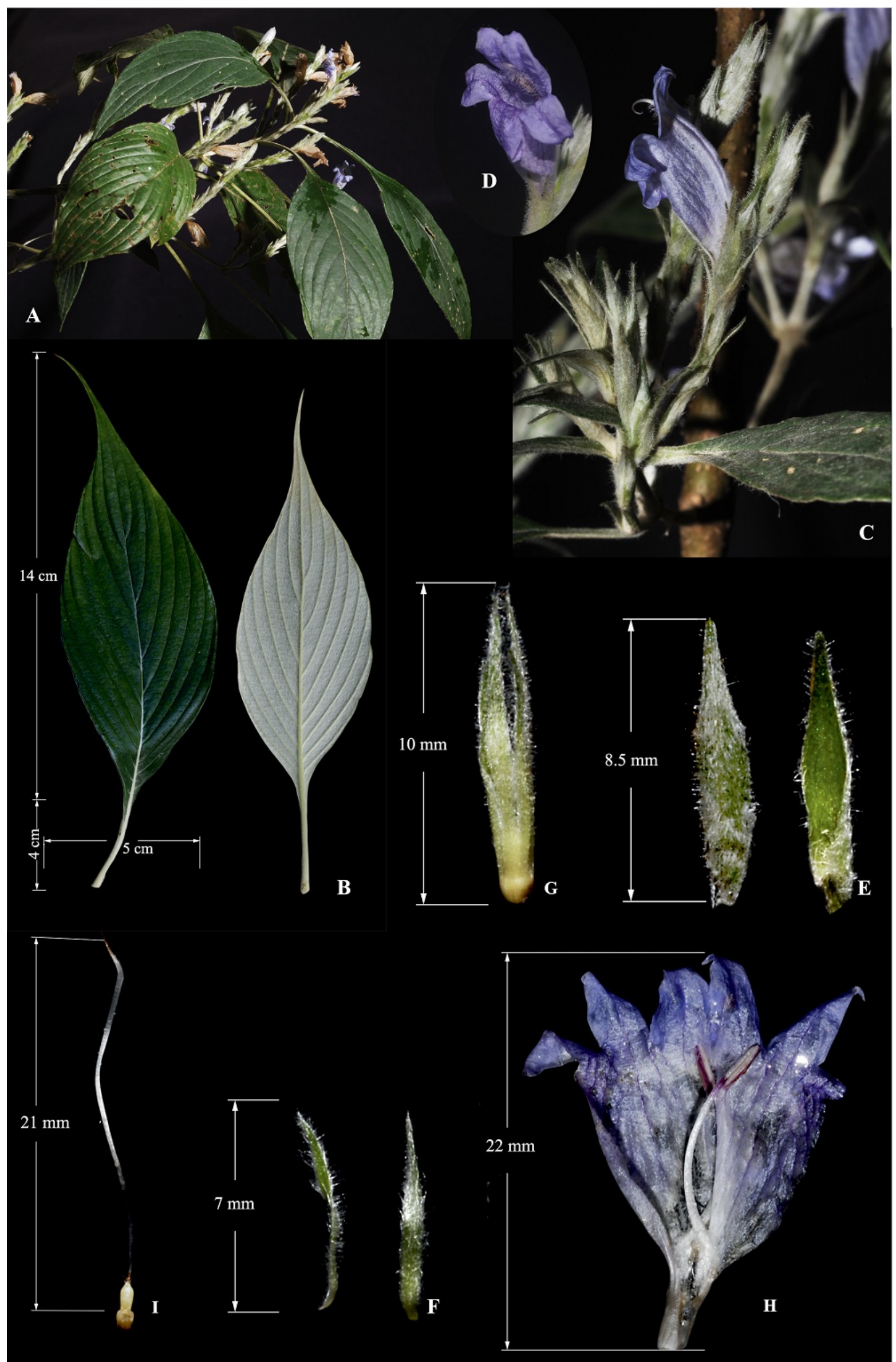

Fig. 3. Strobilanthes bislei sp. nov. A. Flowering twig, B. Leaves, C. Inflorescence, D. Flower, E. Bracts, F. Bracteoles, G. Calyx, H. Corolla split open showing the epipetalous stamens having anthers held parallel to the filament, I. Pistil.

hairs and adaxial surface fine hairy throughout, longer than calyx; bracteoles ca. $6 \times 0.5 \mathrm{~mm}$, linear, indumentum same as in bracts, axillary secondary flower buds absent. Calyx 6.5-7 mm long, tubular, 

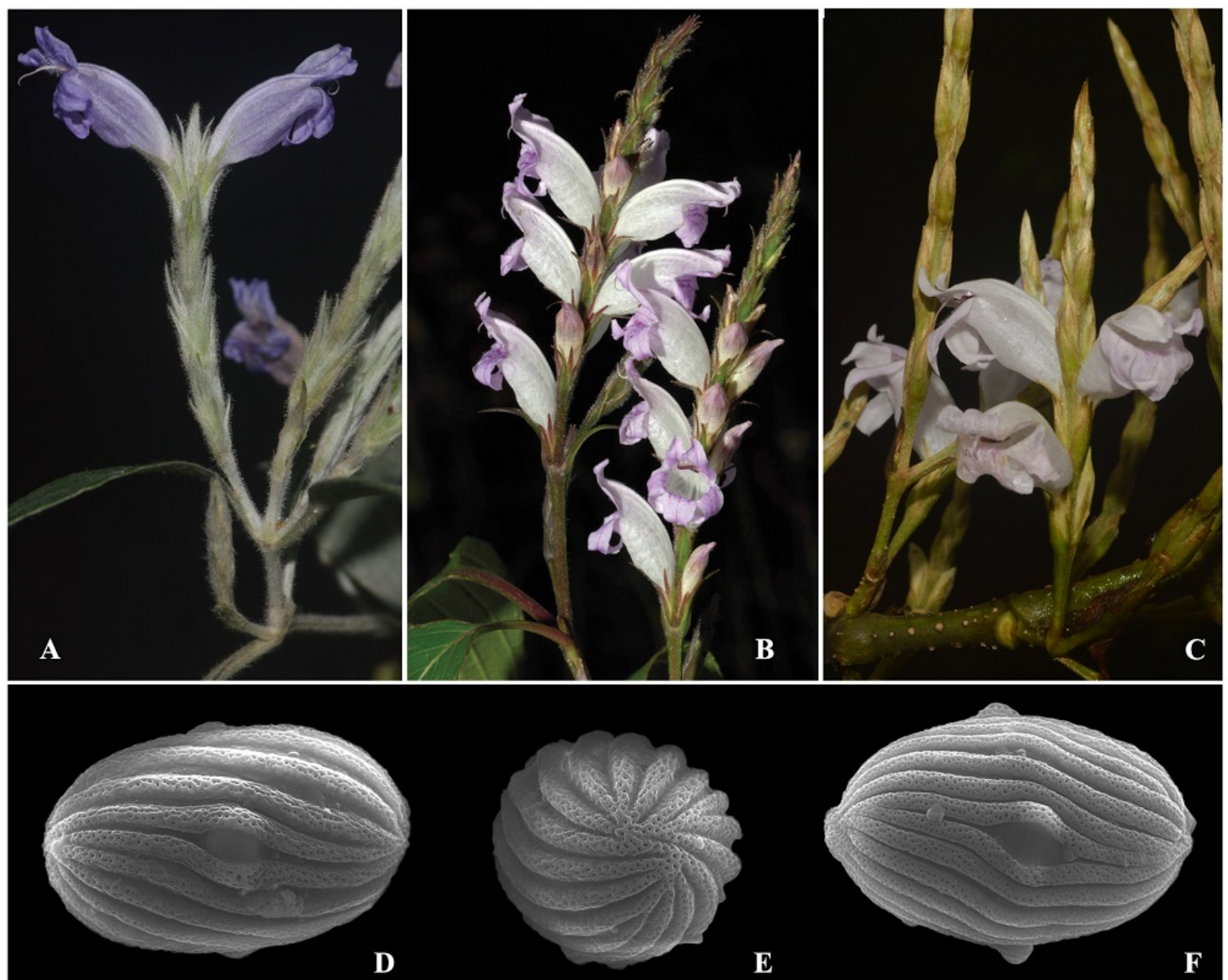

D
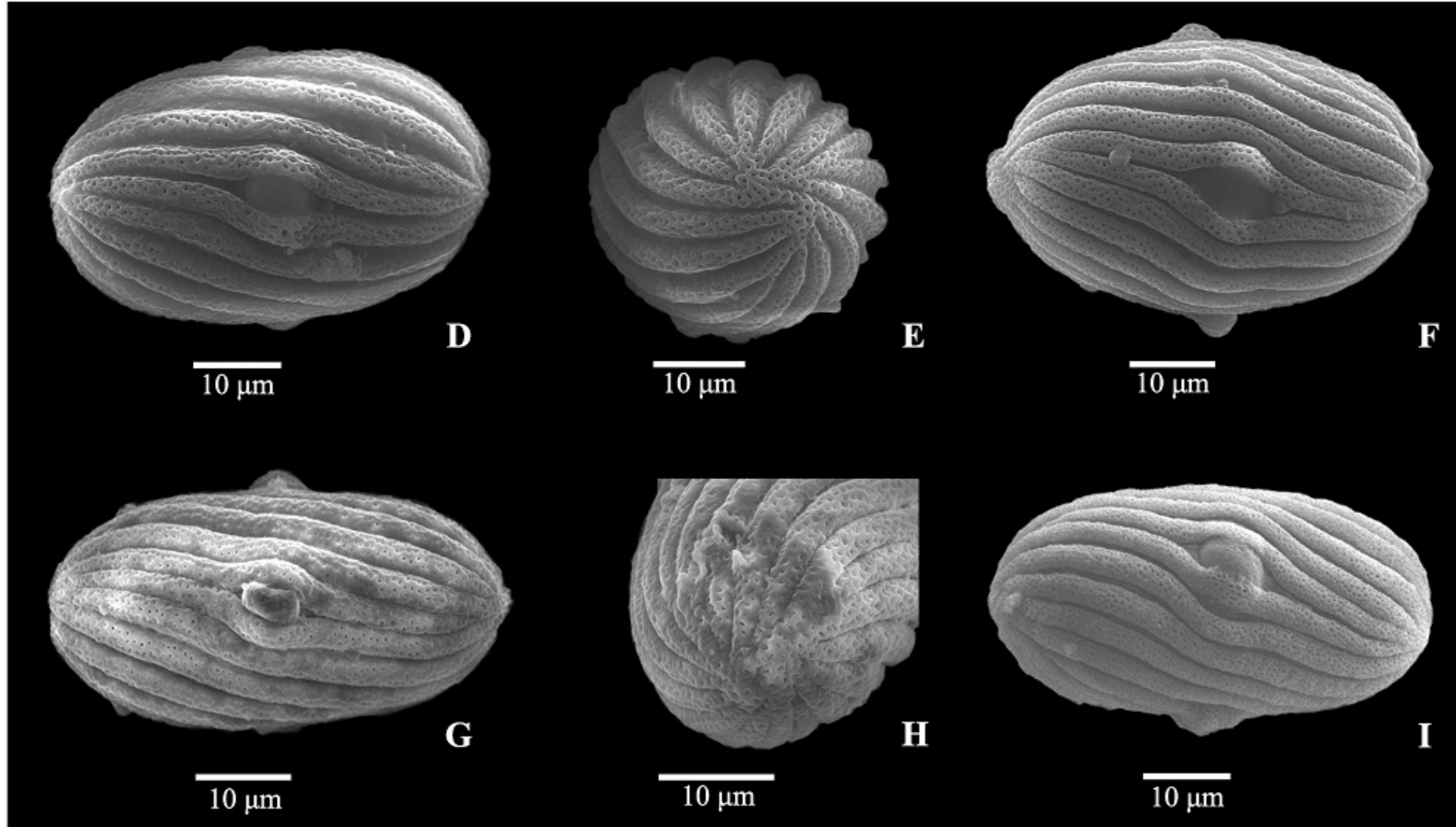

Fig. 4. Inflorescences of Strobilanthes bislei sp. nov. (A), S. consanguinea (B) and S. gamblei (C). SEM images of Strobilanthes mullayanagiriensis sp. nov. (D-E), S. bislei sp. nov. (F), S. consanguinea (G-H) and S. gamblei (I).

5-lobed, tube ca. $3 \mathrm{~mm}$ long, lobes ca. 4mm long, linear, equal, tomentose on the outer surface, pubescent inside. Corolla pale pink, 14-15 mm long, widening from the base, 5-lobed; tube ca. 2 $\mathrm{mm}$ long, glabrous outside, pubescent inside; throat ventricose, ca. $6 \mathrm{~mm}$ long, glabrous on the outer surface, long white hairy inside; lobes unequal, two adaxial lobes partly fused, ca. $3 \times 2$ $\mathrm{mm}$, triangular, abaxial lobes recurved, ca. $5 \times 2.5-$ $3 \mathrm{~mm}$, broadly triangular. Stamens 2, exserted, attached to the base of corolla tube; filaments ca. 6 $\mathrm{mm}$ long, villous on the proximal $1 / 4$; anthers ca. 1.5 $\times 1 \mathrm{~mm}$, elliptic, thecae two, held perpendicular to filament. Pistil 12.5-13 mm long, ovary ca. $1.0 \times 0.5$ $\mathrm{mm}$, pubescent at apex, 2-locular, 2 ovules per locule; style ca. $10 \mathrm{~mm}$ long, filiform, glabrous; stigma simple, ca. $1.5 \mathrm{~mm}$ long, glabrous.

Pollen morphology: Pollen grains are ellipsoid (Fig. 4D-E), tricolporate and contain wide pseudocolpi. It is prolate in outline and exine divided into longitudinal ribs, which are spiral, tectate and coalesces at poles in to two groups. One rib is completely encircling the grain. Tectum is perforate. Comparison of pollen characteristics (Table 1) with the related taxa, $S$. consanguinea (Fig. 4G-H) is also provided.

Etymology: The specific epithet refers to the Mullayanagiri peak which is the highest peak in Baba Budan Giri Hill ranges to which the type locality belongs. 
Table 2: Comparison of diagnostic characters of new species with allied taxa.

\begin{tabular}{|c|c|c|c|c|}
\hline Characters & S. mullayanagiriensis & S. bislei & S. gamblei & S. consanguinea \\
\hline \multicolumn{5}{|l|}{ Lamina } \\
\hline Shape & Broadly ovate & Ovate to elliptic & Ovate to elliptic & Ovate to broadly elliptic \\
\hline Base & Decurrent & Slightly decurrent & Decurrent & Long decurrent \\
\hline Apex & Cuspidate & Caudate- acuminate & Long acuminate & Short to long acuminate \\
\hline Margin & Crenate-serrate & Entire & Entire & Serrate \\
\hline Texture & Coriaceous, scabrous & Membranous & Coriaceous & Membranous \\
\hline Veins & 7-9 pairs & 7-10 pairs & 5-11 pairs & 3-11 pairs \\
\hline $\begin{array}{l}\text { Abaxial } \\
\text { indumentum }\end{array}$ & Short hairs present & Sericeous & $\begin{array}{l}\text { Dense cream or } \\
\text { tawny woolly }\end{array}$ & Often glabrous \\
\hline Inflorescence & $\begin{array}{l}\text { Uninterrupted viscous } \\
\text { spikes }\end{array}$ & $\begin{array}{l}\text { Uninterrupted viscous } \\
\text { spikes }\end{array}$ & $\begin{array}{l}\text { Interrupted non- } \\
\text { viscous spikes }\end{array}$ & $\begin{array}{l}\text { Interrupted spikes, } \\
\text { rarely viscous }\end{array}$ \\
\hline \multicolumn{5}{|l|}{ Bract } \\
\hline Shape & Ovate & Ovate & Ovate-elliptic & Ovate \\
\hline Apex & Long acuminate & Long acuminate & Acute to acuminate & Acuminate \\
\hline $\begin{array}{l}\text { Abaxial } \\
\text { indumentum }\end{array}$ & Tawny & Sericeous & Cream or tawny & Often glabrous \\
\hline Bract: calyx ratio & Longer & Shorter & Equal & Equal \\
\hline $\begin{array}{l}\text { Secondary buds in } \\
\text { axils of bracteoles }\end{array}$ & Absent & Present & Present & Absent \\
\hline \multicolumn{5}{|l|}{ Calyx } \\
\hline Length & ca. $7 \mathrm{~mm}$ & 8-11 mm & $5-9.5 \mathrm{~mm}$ & $4.8-8.1 \mathrm{~mm}$ \\
\hline Apex & Acuminate & Acuminate & Acute & Acute \\
\hline $\begin{array}{l}\text { Abaxial } \\
\text { indumentum }\end{array}$ & Tawny & Sericeous & Cream or tawny & Often glabrous \\
\hline Lobes shape & Linear & Narrowly triangular & Lanceolate & Lanceolate \\
\hline \multicolumn{5}{|l|}{ Corolla } \\
\hline Colour & Pink & Blue & Pink & Pink \\
\hline Tube & ca. $2 \mathrm{~mm}$ & $4-5 \mathrm{~mm}$ & $5-8 \mathrm{~mm}$ & $2.1-4.8 \mathrm{~mm}$ \\
\hline Throat & ca. $6 \mathrm{~mm}$ & $11-12 \mathrm{~mm}$ & $9.5-18 \mathrm{~mm}$ & $7.4-14.8 \mathrm{~mm}$ \\
\hline Lobes shape & Triangular & Triangular & Broadly triangular & Narrowly triangular \\
\hline $\begin{array}{l}\text { Attachment of anther } \\
\text { to filament }\end{array}$ & Held perpendicular & Held parallel & Held perpendicular & Held perpendicular \\
\hline
\end{tabular}

December.

Phenology: Flowers during November-

Habitat and distribution: It grows in the open rocky cliffs in the Baba Budan Giri Hills, Chikkamagaluru District in Karnataka at elevation of 1600-1800 m MSL.

Taxonomic notes: Strobilanthes mullayanagiriensis and $S$. consanguinea possesses spicate inflorescence with ventricose corolla and exserted stamens. However, the new species could readily be distinguished from the allied species by the characteristics such as bushy habit, coriaceous and scabrous leaves with broadly ovate lamina, crenate margin and cuspidate apex, puberulent abaxial lamina surface, uninterrupted viscous spikes, tawny abaxial bract indumentum and longer bract: calyx ratio, calyx lobes linear with acuminate apex, Etc. A detailed comparison of vegetative and floral characters is given in Table 2.

The variability of pollen morphology in Strobilanthes is a useful character to delimit taxa in this group (6-7). The pollen morphology of south Indian and Sri Lankan Strobilanthes was well documented and recognised (6). The new species and $S$. consanguinea have prolate pollen with spiral ribs. The pollen of $S$. consanguinea is characterized by having narrow psudocolpi, closely packed ribs, tectum is present on entire surface of the ribs and ribs coalesces at the poles in one group. At the same time, the pollen of $S$. mullayanagiriensis is distinguished by having wide psudocolpi, narrow ribs with tectum on top surface only and the ribs meet at the poles into two groups and one rib completely encircling the pollen. Moreover, the present and previous (6) studies have revealed that the pollen of $S$. consanguinea belongs to type I class and that of $S$. mullayanagiriensis is belongs to type II class (6). Therefore, by the analysis of vegetative, floral and micro morphological features suggested that $S$. mullayanagiriensis as a distinct species from its allied one. 
Strobilanthes bislei S. Thomas, B. Mani, S.J. Britto \& Pradeep A.K., sp. nov. (Fig. 3)

The new species is allied to $S$. consanguinea and S. gamblei Carine, J. Alexander \& Scotland, however it differs from the allied taxa by possessing sericeous stem, leaves and inflorescence, lamina with 7-10 lateral nerves, uninterrupted viscous spikes, shorter bract: calyx ratio, larger calyx with sericeous indumentum, narrowly triangular calyx lobes with acuminate apex and blue corolla. Moreover, large ellipsoid pollen grains with 20-24 ribs are also the distinguishing feature of the new species.

Type: INDIA. Karnataka: Hassan District, Bisle Ghat, 800 m MSL., 19 November 2018, Pradeep A.K. \& B. Mani 68841 (holotype RHT!; isotype MH!, RHT!).

Erect shrubs, up to $2.5 \mathrm{~m}$ tall; young shoots 4-angled, canaliculated, densely sericeous, terete at maturity, tomentose, lenticellate. Leaves opposite, ovate to elliptic, 9.5-21 × 3-9.5 cm, membranous, attenuate at base, caudate-acuminate at apex, margin entire, dense sericeous on abaxial surface, young leaves with sparse sericeous hairs on adaxial surface, mature leaves with short hairs throughout on adaxial surface; lateral nerves 7-10 pairs, prominent on both surfaces, raised beneath; petiole 4-11 cm long, sericeous. Inflorescences axillary, terminal or lateral uninterrupted spikes, 60-85 × 5-7 mm, 1-3 forked, dense sericeous and glandular hairy at anthesis; peduncle quadrangular, sericeous with glandular hairs; bracts ovate, $7.5-8.5 \times$ ca. $2 \mathrm{~mm}$, shorter than calyx, acuminate at apex, abaxial surface glandular hairy and sericeous, adaxial surface glabrous; bracteoles 6-7 × 0.5-0.75 mm, linear, sericeous with glandular hairs. Calyx 10-11 mm long, tubular, tube 3.5-4 mm, 5-lobed, unequal, two lobes shorter than the rest, shorter lobes 4.5-5 $\mathrm{mm}$ long, longer lobes 6.5-7 mm long, narrowly triangular, acuminate at apex, dense sericeous with glandular hairs outside, glabrous inside. Corolla blue, 19-23 mm long, widening from the base, 5-lobed; tube $4-5 \mathrm{~mm}$ long, glabrous; throat ventricose, 11-12 mm long, puberulent on outside, long white hairy inside; lobes unequal, fine pubescent outside, glabrous inside, two adaxial lobes partly fused, ca. $3 \times 2-3 \mathrm{~mm}$, triangular, abaxial lobes 4-5 × 3-4 mm. Stamens 2, exserted, basally attached to corolla tube; filaments 9-10 $\mathrm{mm}$ long, glabrous; anthers ca. $3 \times 1 \mathrm{~mm}$, oblong, thecae two, held parallel to the filament. Pistil 21$23 \mathrm{~mm}$ long, ovary ca. $2 \times 1 \mathrm{~mm}$, pubescent towards apex, 2-locular, 2 ovules per locule; style 16-18 mm long, filiform, glabrous; stigma simple, curved, ca. $3 \mathrm{~mm}$ long, glabrous.

Pollen morphology: Pollen grains are ellipsoid (Fig. 4F), tricolporate and contain wide pseudocolpi. It is prolate in outline and exine divided into longitudinal ribs, which are slightly spiral, tectate and coalesce at poles. None of the ribs is completely encircling the grain. Tectum is perforate. Comparison of pollen characteristics (Table 1) with the related taxa, $S$. consanguinea (Fig. 4G-H) and S. gamblei (Fig. 4I) is also provided.

Etymology: The specific epithet refers to Bisle Ghat which harbours rich biodiversity and is part of the central Western Ghats. The Bisle Reserve Forest of Gundia river basin, constitutes a vital part of the Mysore Elephant Reserve. It covers an area of 3,339 ha with annual rainfall in the range of $500-600 \mathrm{~cm}$. The reserve mainly consists of species rich evergreen forests have high degree of Western Ghats endemism both among the trees as well as among the ground vegetation. It connects Pushpagiri Wildlife Sanctuary in the south and Kempholé Reserve Forest in north. It is an intrinsic and important part of the Mudumalai Nagarhollé - Brahmagiri - Muttodi Corridor (8).

\section{November.}

Phenology: Flowering on October-

Habitat and distribution: It grows on the exposed rocks in the Bisle Ghat forest reserves in Hassan District in Karnataka at an elevation of 700-800 m a.s.l.

Taxonomic notes: Strobilanthes bislei, $S$. consanguinea and $S$. gamblei have spicate inflorescence with ventricose corolla and exserted stamens. However, the new species could readily be distinguished by the uninterrupted viscous inflorescence with sericeous indumentum (Fig. $4 \mathrm{~A}-\mathrm{C})$. Another striking diagnostic feature of the new species from the allied taxa is the presence of much longer calyx with narrowly triangular lobes which exceeds the bract (Table 2). The corolla of $S$. bislei is blue in colour whereas that of the allied species is pink (Fig. 4A-C). Moreover, anthers are held parallel to the filament in new taxon while it is held perpendicular in $S$. consanguinea and $S$. gamblei. Finally, ellipsoid pollen grains with slightly twisted ribs are characteristic in S. bislei. A detailed comparison of $S$. bislei with the allied species is given in Table 1 and Table 2.

\section{Competing interest}

Authors declare that we have no competing interest.

\section{Authors' contributions}

All authors contributed equally to the present work.

\section{Acknowledgements}

The authorities of Rapinat Herbarium, St. Thomas College Palai and Carmel College Mala are gratefully acknowledged for providing facilities. The authors are grateful to curators of $\mathrm{K}, \mathrm{P}, \mathrm{C}, \mathrm{CAL}$, CALI and $\mathrm{MH}$ for giving kind permission for herbarium analysis. 


\section{References}

1. UNESCO. Twenty-six new sites inscribed on UNESCO World Heritage List this year. Published on the Internet; http://whc.unesco.org/en/news/903/ Retrieved 05 May 2018.

2. Carine MA, Scotland RW. Classification of Strobilanthinae (Acanthaceae): trying to classify the unclassifiable? Taxon 2002; 51: 259-279. http://www.jstor.org/stable/1554926.

3. Venu P. Strobilanthes Blume (Acanthaceae) in Peninsular India. Botanical Survey of India, Kolkata, p.216. 2006.

4. Thomas S, Mani B, Britto SJ. Strobilanthes orbiculata (Acanthaceae) a new species and notes on $S$. matthewiana from the southern Western Ghats, India. Phytotaxa 2018; 369: 047-055. http://doi.org/10.11646/phytotaxa.369.1.5

5. Carine MA, Alexander JM, Scotland RW. A revision of the Strobilanthes kunthiana-group
(Phlebophyllum sensu Bremekamp) (Acanthaceae). Kew Bull. 2004; 59: 1-25.

6. Carine MA, Scotland RW. Pollen morphology of Strobilanthes Blume (Acanthaceae) from southern India and Sri Lanka. Rev Palaeobot Palynol. 1998; 103: 143-165. $\quad$ http://doi.org/10.1016/S00346667(98)00030-X.

7. Deng YF, Wood JRI, Scotland RW. New and reassessed species of Strobilanthes (Acanthaceae) in the flora of China. Bot J Linn Soc. 2006; 150: 369390. https://doi.org/10.1111/j.10958339.2006.00473.x

8. IISc. Biodiversity, Ecology and Socio-Economic Aspects of Gundia River Basin in the context of proposed Mega Hydro Electric Power Project. Published on the Internet; http://wgbis.ces.iisc.ernet.in/biodiversity/pubs/ces t r/TR122/index.htm Retrieved 03 January 2019. 